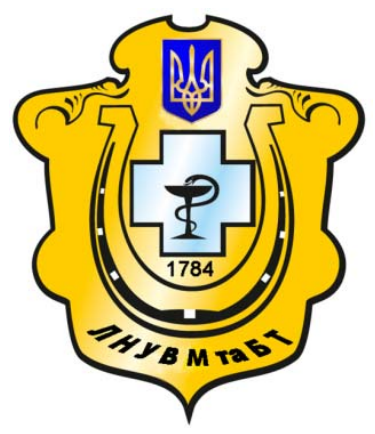

Науковий вісник Львівського національного університету ветеринарної медицини та біотехнологій імені С.3. Гжицького

Scientific Messenger of Lviv National University of Veterinary Medicine and Biotechnologies named after S.Z. Gzhytskyj

doi:10.15421/nvlvet7717

ISSN 2518-7554 print

ISSN 2518-1327 online

$\underline{\text { http://nvlvet.com.ua/ }}$

УДК 619:636.02:636.08.003

\title{
Гістологічна, гістохімічна характеристика дванадцятипалої кишки курей- бройлерів за згодовування кормів з високим вмістом пробіотичної добавки
}

\author{
Г.І. Коцюмбас, А.К. Костинюк, О.В. Мисів, Ю.Я. Федик
} galyna.kotsymbas@gmail.com, anastasija.kostunyk@gmail.com

Львівський наџіональний університет ветеринарної медицини та біотехнологій імені С.З. Гжицького, вул. Пекарська, 50, м. Львів, 79010, Украӥна

\begin{abstract}
У статті представлені результати гістологічних, гістохімічних досліджень слизової оболонки дванадиятипалої кишки курей-бройлерів, яким згодовували 36 діб поспіль комбікорм з пробіотичною добавкою «Probion forte» в дозі 100 г/кг. На 36 добу досліду по 10 курчат з кожної групи виводили з експерименту, проводили розтин і відбирали взіриі дванадиятипалої кишки, які фіксували у 10\% розчині нейтрального формаліну, рідині Карнуа з подальшою заливкою у парафін. Виготовляли гістозрізи, фарбували гематоксилін-еозином, за Стідменом, Мак-Манусом.

Тривале згодовування птиці кормів з пробіотичною добавкою "Probion forte» в надмірній дозі 100 г/кг спричинило структурно-функціональні зміни у слизовій оболонці дванадиятипалої кишки, щзо виразилось утворенням виродливих роздвоєних, широких ворсинок, зниженням вмісту глікозаміногліканів, щяо свідчило про дисфункиію ворсинок $i$ відобразилось зниженням продуктивних показників птиці.

Ключові слова: кури-бройлери, пробіотичні добавки, дванадиятипала кишка, ворсинки, крипти, келихоподібні клітини, гістоструктура, гістохімія.

\section{Гистологическая, гистохимическая характеристика двенадцатиперстной кишки кур-бройлеров при скармлевании кормов с высоким содержанием пробиотических добавок}

\author{
Г.И. Коцюмбас, А.К. Костынюк, А.В. Мысив, Ю.Я. Федык \\ galyna.kotsymbas@gmail.com, anastasija.kostunyk@gmail.com
}

Львовский национальный университет ветеринарной медицины и биотехнологий имени С.3. Гжицякого, ул. Пекарская, 50, г. Львов, 79010, Украина

\begin{abstract}
В статье представлены результаты гистологических, гистохимических исследований слизистой оболочки двенадиятиперстной кишки кур-бройлеров, которым скармливали 36 суток подряд комбикорм с пробиотической добавкой «Ргоbіоп forte» в дозе 100 г/кг. На 36 сутки опыта по 10 иьлплят из каждой группы выводили из эксперимента, проводили вскрытие и отбирали образиы двенадиатиперстной кишки, которые фиксировали в $10 \%$ растворе нейтрального формалина, жидкости Карнуа с последующей заливкой в парафин. Изготавливали гистосрезы окрашивали гематоксилин-эозином, по Стидмен, Мак-Манус.

Длительное скармливание птиче кормов с пробиотической добавкой «Probion forte» в чрезмерной дозе 100 г/кг привело к структурно-функииональным изменениям в слизистой оболочке двенадиатиперстной кишки, что выразилось образованием уродливых раздвоенных, иироких ворсинок, снижением содержания гликозаминогликанов, что свидетельствовало о дисфункиии ворсинок и отразилось снижением производительных показателей птицы.

Ключевые слова: куры-бройлеры, пробиотические добавки, двенадиатиперстная кишка, ворсинки, крипты, гистоструктура, гистохимия.
\end{abstract}

\section{Citation:}

Kotsyumbas, G., Kostynjuk, A., Mysiv, O., Fedyk, Yu. (2017). Histological, histochemical characteristics of duodenal intestine of hen-broilers for feed feeding with high content of probiotic supplements. Scientific Messenger LNUVMBT named after S.Z. Gzhytskyj, 19(77), 71-75. 


\title{
Histological, histochemical characteristics of duodenal intestine of hen-broilers for feed feeding with high content of probiotic supplements
}

\author{
G. Kotsyumbas, A. Kostynjuk, O. Mysiv, Yu. Fedyk \\ galyna.kotsymbas@gmail.com, anastasija.kostunyk@gmail.com \\ Lviv National University of Veterinary Medicine and Biotechnologies named after S.Z. Gzhytskyi, \\ Pekarska Str., 50, Lviv, 79010, Ukraine
}

\begin{abstract}
The article presents results of histological, histochemical investigations of duodenal mucosa of broilers, which were fed 36 days in a row with were fed 36 days in a row with fodder mixed of probiotic supplements «Probion forte» in doses of $100 \mathrm{~g} / \mathrm{kg}$. At $36 \mathrm{day}$ of the experiment 10 chickens from each group were taken out from the experiment, was performed autopsy and selected models of duodenum, which are fixed in 10\% of solution neutral formalin, Karnua liquid, followed by pouring into paraffin. It was produced histological sections, were stained with hematoxylin-eosin, by Stidmen, McManus.

Prolonged feeding of poultry with probiotic supplements "Probion forte» in excessive dose of $100 \mathrm{~g} / \mathrm{kg}$ has caused structural and functional changes in the mucosa of the duodenum, expressed the formation of ugly bifurcated broad villi and reflected a decrease in productive indexes of poultry.
\end{abstract}

Key words: chickens-broilers, probiotic preparations, duodenum, villi, crypts, goblet cells, histostructure, histochemistry.

Ветуп

Кишечник птиці є одним з найважливіших відділів травної системи, у якому відбуваються складні фізіологічні, біохімічні процеси перетравлення та всмоктування поживних речовин. Стрес, порушення режиму та якості годівлі може спричинити стійкі зміни в кишечнику та негативно вплинути на загальний стан організму птиці (Pavlova et al., 2002; Samarcev et al., 2007).

Сьогодні при вирощуванні птиці широко використовують різноманітні пробіотичні кормові добавки, які містять живі мікроорганізми, що пов'язані з нормофлорою кишечнику. Застосування їх грунтується на можливості заселення кишечнику мікроорганізмами, які за рахунок антагоністичних властивостей, пригнічують ріст патогенних та умовно-патогенних бактерій (Malik and Panin, 2001; Lytvyn and Polishchuk, 2008).

Нами попередньо було встановлено, що при згодовуванні курам-бройлерам з кормом пробіотичної добавки «Probion forte» в дозі 1 г/кг і 0,5 г/кг в дванадцятипалій кишці вірогідно збільшувалась довжина ворсинок слизової оболонки, товщина стінки м'язової оболонки. Це вказує на інтенсифікацію процесів травлення слизовою оболонкою і більшу рухову активність м'язової оболонки та впливає на покращенням обмінних процесів і зростання продуктивних показників птиці (Kotsiumbas and Kostyniuk, 2012; Kotsiumbas et al., 2012).

Разом 3 тим виникла потреба в оцінці безпеки застосування кормових добавок (толерантності), що включає визначення рівня «запасу безпечності», коли кормова добавка може використовуватись у більших дозах, ніж рекомендовано (Levytskyi, 2013; Levytskyi, 2015).

Тому метою нашої роботи було вивчити гістологічні, гістохімічні особливості слизової оболонки дванадцятипалої кишки курей-бройлерів, яким згодовували комбікорми 3 пробіотичною кормовою добавкою «Probion forte» в дозі 100 г/кг 36 діб поспіль.

\section{Матеріал та методи дослідження}

Дослід проводили на курчатах-бройлерах породи «Kobb-500» в умовах віварію. Було сформовано дві дослідні групи курей-бройлерів, масою тіла 37-40 г, по 10 голів у кожній. Птиця утримувалась на підлозі 3 вільним доступом до води та їжі. Курчатамбройлерам контрольної групи (І група) згодовували комбікорм без пробіотчної добавки. Кури II групи отримували комбікорм 3 пробіотичною добавкою «Probion forte» в дозі 100 г/кг корму поспіль 36 днів. На 36 добу досліду по 10 курчат з кожної групи зважували, виводили з експерименту, проводили розтин i відбирали шматочки дванадцятипалої кишки, фіксували у $10 \%$ р-ні нейтрального формаліну, рідині Карнуа, з подальшою заливкою у парафін. Зрізи виготовлялись на мікротомі МC-2 і фарбували: гематоксиліном та еозином, альціановим синім, за Мак-Манусом (PAS-реакція) (Merkulov, 1961; Horalskyi et al., 2005). Мікроскопію та фотографування проводили за допомогою мікроскопа OLIMPUS CX-41 та морфометричної програми DP-SOFT.

\section{Результати та обговорення}

Кури-бройлери I групи були активними, добре поїдали корми, тимчасом як у курей II групи відзначали періодичні розлади травлення, але загибелі серед них не спостерігали. Маса тіла курей в контрольній груп в кінці досліду становила $1661,7 \pm 69,2$, тимчасом як у птиці II групи $-1420 \pm 51,3$ г, тобто була меншою на $15 \%$ порівняно з контрольною.

Макроскопічно слизова оболонки кишок курейбройлерів контрольної та дослідної груп були подібними: світло-рожевими, вологими. За світлооптичного дослідження слизової оболонки контрольної групи ворсинки довгі, пальцеподібної форми, чітко контуровані, вільно розміщувались одна біля одної і були спрямовані у просвіт кишки (рис. 1). Циліндричний епітелій мав виражену облямівку (рис. 2). У стінці ворсинки між епітеліоцитами добре проглядались окремі лімфоцити. 
Серед стовпчастих епітеліоцитів, які складали основну масу епітеліального пласту ворсинки, вирізнялись келихоподібні клітини та кишкові ендокриноцити. Келихоподібні, видовжено-грушевидної форми клітини розміщувались поодиноко і добре виявлялись на гістопрепаратах при фарбуванні за Стідменом. Вони набували синього забарвлення, що вказувало на вміст у секреті келихоподібних клітинах глікозаміно-



Рис. 1. Ворсинки і критпи дванадцятипалої кишки курей контрольної групи.

Гематоксилін та еозин. Ок. 10, об. 10

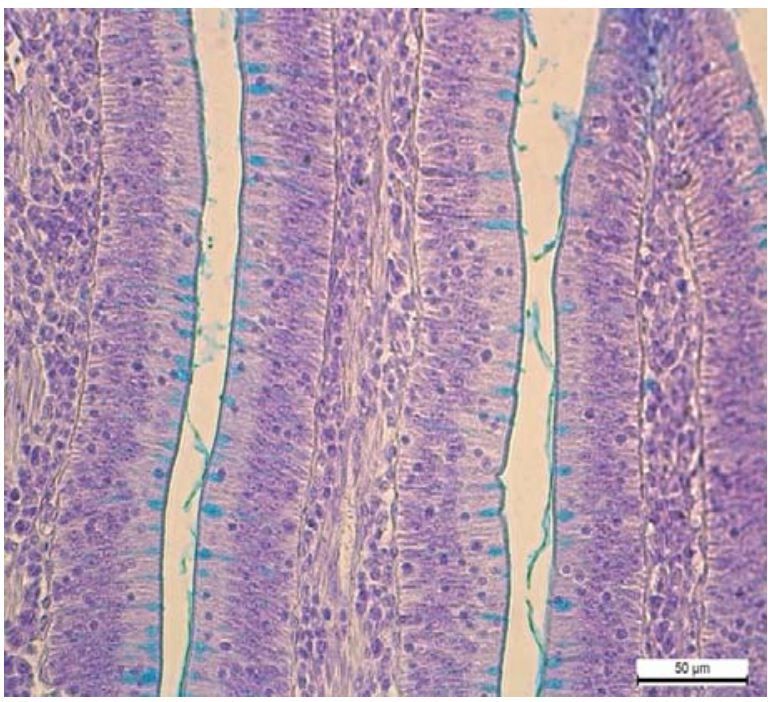

Рис. 3. Альціанофільні келихиподібні клітини та біоплівка ворсинок дванадцятипалої кишки курей контрольної групи. Стідмен. Ок. 10, об. 40

У дванадцятипалій кишці курей II групи, яким 3 кормом згодовували пробіотичну добавку «Probion forte» в дозі 100 г/кг, на 36 добу досліду ворсинки, порівняно з контрольною групою були товстішими, коротшими, покрученими. Відзначали збільшення ширини ворсинок, потовщення власної пластинки слизової оболонки, збільшення кількості крипт (рис. 5). Відомо, що джерелом регенерації епітелію є стовпчасті епітеліоцити без облямівки, які містяться у криптах. Ймовірно, що проліферативна активність гліканів. На поверхні ворсинок також виділялось тоненька альціанофільна облямівка (рис. 3). У реакції за Мак-Манусом ( PAS-реакція ) - келихоподібні клітини набували малинового кольору (рис. 4). Утворення келихоподібними клітинами слизистого секрету, багатого глікозаміногліканами сприяло формуванню захисної біоплівки. У власній пластинці слизової оболонки проглядалися крипти видовженої форми.

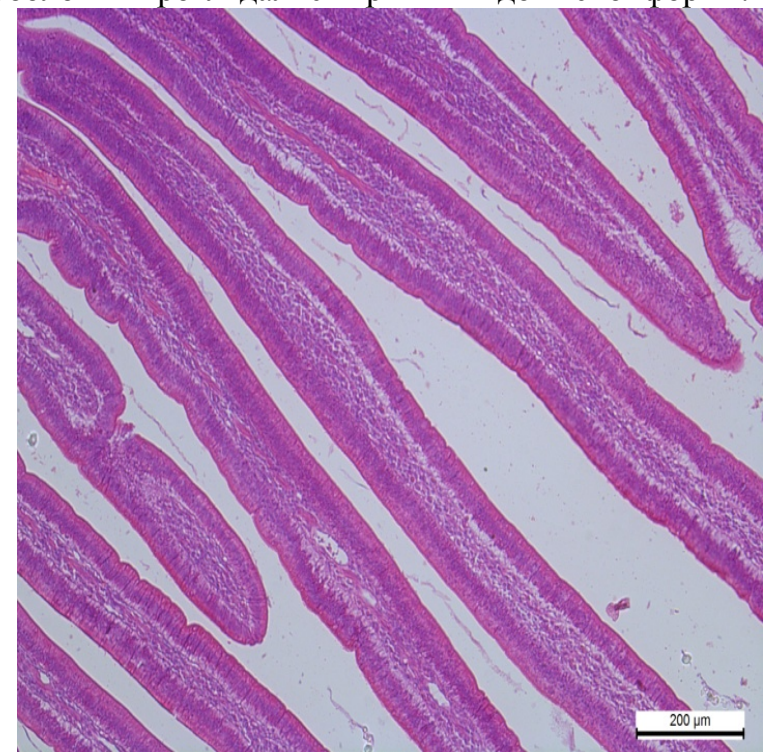

Рис. 2. Ворсинки дванадцятипалої кишки курей контрольної групи, вистелені циліндричним епітелісм, з вираженою облямівкою. Гематоксилін та еозин. Ок. 10, об. 20

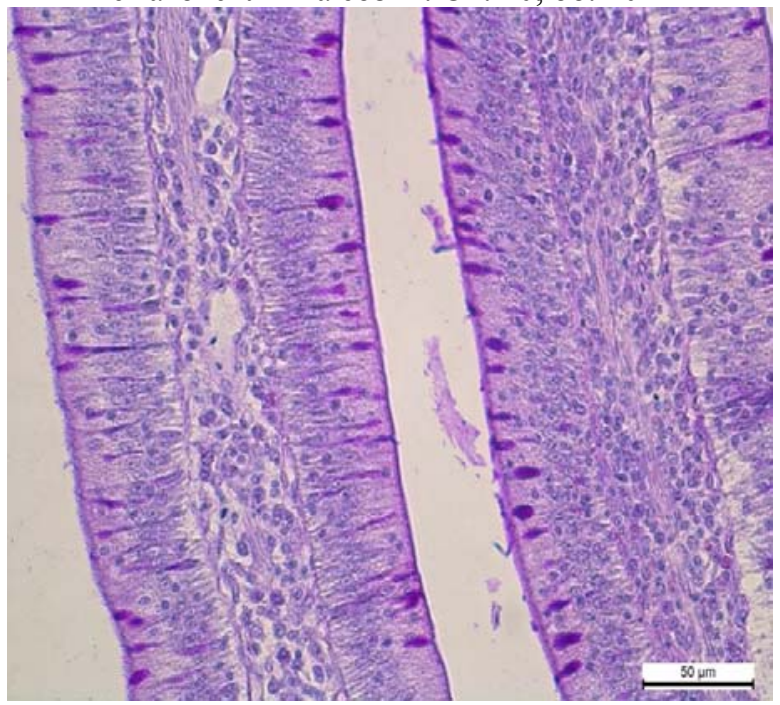

Рис. 4. PAS-позитивні келехиподібні клітини і поверхня ворсинок дванадцятипалої кишки курей контрольної групи. Мак-Манус. Ок. 10, об. 40

цих клітин зумовила потовщення структур як власної пластинки слизової оболонки, так і епітеліального пласту ворсинок. У процесі збільшення ширини ворсинок зростала кількість стовпчастих епітеліоцитів та келихоподібних клітин. Сполучна тканина ворсинок даної групи птиці була густо інфільтрована лімфоцитами та плазматичними клітинами. Часто серед ворсинок виділялись роздвоєні або короткі та широкі, вкриті еозинофільною плівкою (рис. 6). 


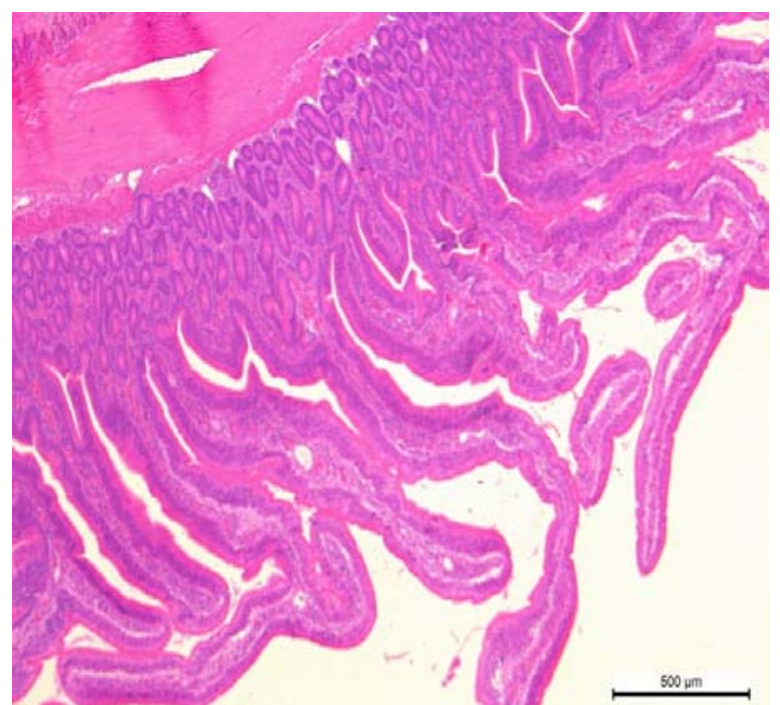

Рис. 5. Слизова оболонка дванадцятипалої кишки курей II групи. Ворсинки хаотично розміщені.

Гематоксилін та еозин. Ок. 10, об. 10

На препаратах, забарвлених альціановим синім за Стідменом, у потовщених, складчастих ворсинках та криптах курей II групи між стовпчастими епітеліоцитами проглядались хаотично розміщені, видовженої форми келихоподібні клітини, помірно заповнені глікозаміногліканами. При цьому слід відзначити, що біоплівка ворсинок не приймала альціанофільного забарвлення, що вказує на зниження секреції глікозаміногліканів (рис. 7). У реакції за Мак-Манусом (PAS-реакція ) келихоподібні клітини виділялись

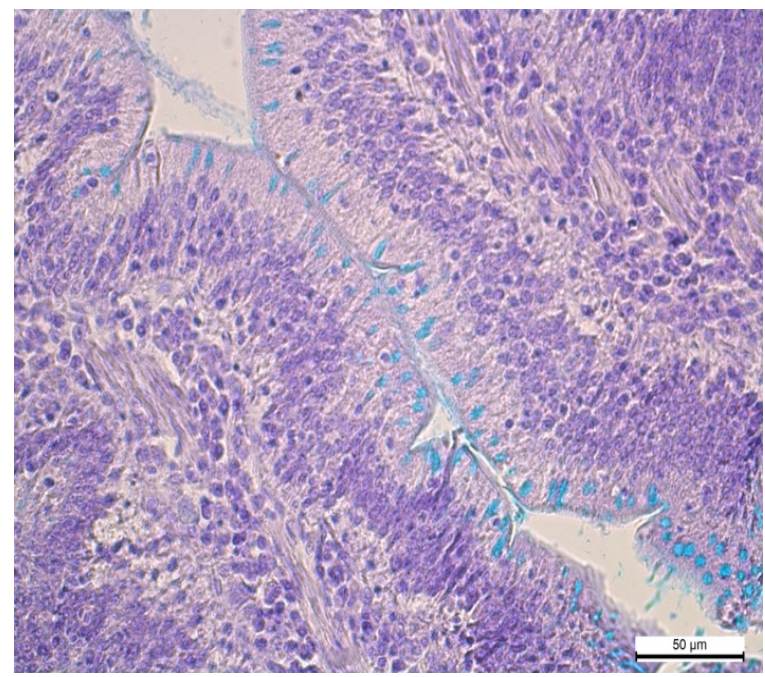

Рис. 7. Альціанофільні келихиподібні клітини у потовщених ворсинках дванадцятипалої кишки курей II групи. Стідмен. Ок. 10, об. 40

\section{Висновки}

Тривале згодовування птиці кормів 3 пробіотичною добавкою «Probion forte» в надмірній дозі 100 г/кг спричинило структурно-функціональні зміни у слизовій оболонці дванадцятипалої кишки, що викликало зниження продуктиктивних показників птиці.

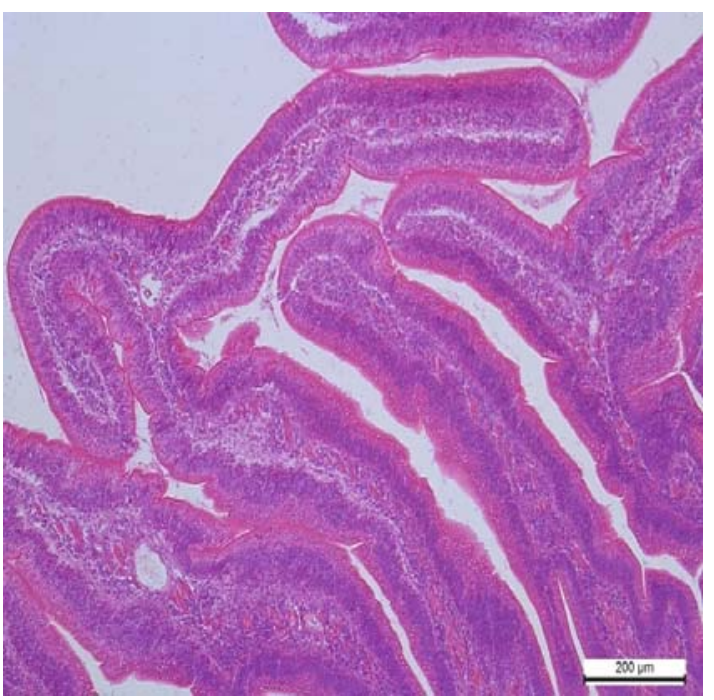

Рис. 6. Ворсинки слизової оболонка дванадцятипалої кишки курей II групи потовщені і роздвосні. Стідмен. Ок. 10, об. 20

серед стовпчастих клітин своїм малиновим забарвленням. Разом з тим слизиста біоплівка ворсинок також проявляла слабо виражену PAS-реакцію, що вказувало на зростання у слизистому секреті нейтральних мукополіцукрів та зниження кислих (рис. 8). У гістохімії вуглеводів PAS-реакція відіграє важливу діагностичну роль при ідентифікації глікопротеїнів, поліцукрів, деяких мукополіцукрів, глікопротеїдів і ряду жирних кислот (Sreekumar and Hosono, 1998; Guo et al., 2004).

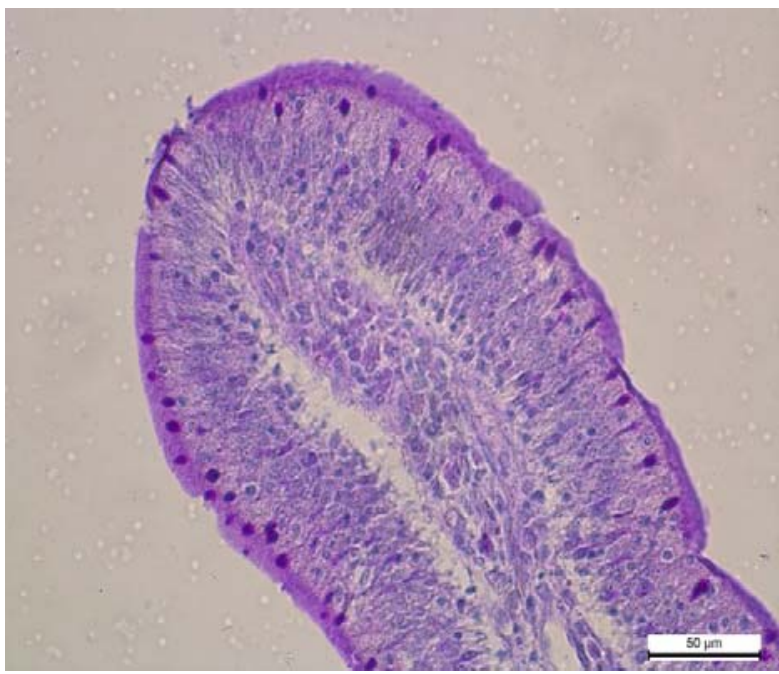

Рис. 8. PAS-позитивні келехиподібні клітини і

біоплівка ворсинки дванадцятипалої кишки курей контрольної групи. Мак-Манус. Ок. 10, об. 40

\section{Бібліографічні посилання}

Pavlova, N.V., Kirzhaev, F.S., Lapinskajte, R. (2002). Znachenie normal'noj mikroflory pishhevaritel'nogo trakta ptic dlja ih organizma. Bio. 1, 48-50 (in Russian).

Samarcev, A.A., Astanovich, N.I., Novik, G.I. (2007). Novye probiotiki dlja zhivotnovodstva. Efektivni kormi ta godivlja. 2(18), 14-15 (in Russian). 
Lytvyn, V.P., Polishchuk, V.V. (2008). Porivnialna efektyvnist vitchyznianykh probiotykiv pry kyshkovykh zakhvoriuvanniakh molodniaku tvaryn. Visnyk Poltavskoi derzhavnoi ahrarnoi akademii. 1, 123-127 (in Ukrainian).

Malik, N.I., Panin, A.N. (2001). Veterinarnye probioticheskie preparaty. Veterinarija. 1, 46-51 (in Russian).

Kotsiumbas, H.I., Kostyniuk, A.K. (2012). Histokhimichna ta ultrastrukturna kharakterystyka dvanadtsiatypaloi kyshky u kurei-broileriv vplyvu probiotykiv, zastosovanykh u riznykh dozakh. Naukovyi visnyk LNUVMBT imeni S.Z. Hzhytskoho. 14, 3(53), 128-136 (in Ukrainian).

Kotsiumbas, H.I., Shchebentovska, O.M., Kostyniuk, A.K. (2012). Histolohichni ta morfolohichni pokaznyky dvanadtsiatypaloi kyshky u kurei-broileriv za vplyvu probiotykiv, zastosovanykh u riznykh dozakh. Naukovyi visnyk LNUVMBT imeni S.Z. Hzhytskoho. 14, 2(52), 74-80 (in Ukrainian).

Levytskyi, T.R. (2013). Zahalni pidkhody do otsinky bezpechnosti kormovykh dobavok. Naukovotekhnichnyi biuleten Instytutu biolohii tvaryn i DND-
KI vetpreparativ ta kormovykh dobavok. 14, 3(4), 301-308 (in Ukrainian).

Levytskyi, T.R. (2015). Otsinka bezpechnosti kormovoi dobavky liatsyd. Naukovo-tekhnichnyi biuleten Derzhavnoho naukovo-doslidnoho kontrolnoho instytutu veterynarnykh preparativ ta kormovykh dobavok i Instytutu biolohii tvaryn. 16(2), 102-105 (in Ukrainian).

Merkulov, G.A. (1961). Kurs patogistologicheskoj tehniki. L. Izd. med. literatury (in Russian).

Horalskyi, L.P. Khomych, V.T., Kononskyi, O.I. (2005). Osnovy histolohichnoi tekhniky i morfofunktsionalni metody doslidzhen u normi ta pry patolohii. Navchalnyi posibnyk. Zhytomyr. Polissia (in Ukrainian).

Sreekumar, O., Hosono, A. (1998). The antimutagenic of properties of a polysaccharide produced by Bifidobacterium longum and its cultured milk against some heterocyclicamines. Can. J. Microbiol. 44, 1029-1036.

Guo, F.C., Williams, B.F., Kwakkel, R.P. et. al. (2004). Effect of mushrooms and herb polysaccharides, as alternatives for an antibiotic, on the cecal microbial ecosystem in broiler chickens. J. Poult. Sci. 83, 175-182.

Стаття надійшла до редакиії 11.03.2017 